\title{
ASPECTOS JURÍDICOS DO PAGAMENTO POR SERVIÇOS AMBIENTAIS NO BRASIL
}

\section{LEGAL ASPECTS OF PAYMENT FOR ENVIRONMENTAL SERVICES IN BRAZIL}

\author{
${ }^{1}$ Mariana Gomes Welter \\ ${ }^{2}$ Patrícia Campolina Vilas Boas
}

\section{RESUMO}

O presente artigo objetiva analisar os conceitos disponíveis e os principais objetivos do instituto denominado Pagamento por Serviços Ambientais PSA ou Ecossistêmicos, partindo da análise das normas existentes e do mapeamento dos principais projetos de lei apresentados na Câmara dos Deputados e no Senado, que versem sobre o tema. Pretende-se investigar se os sistemas de PSA podem ser reconhecidos como uma política pública ambiental válida, em consonância com as previsões constitucionais e com os princípios do Direito Ambiental, bem como se podem auxiliar na conservação e uso sustentável dos ecossistemas. Para tanto, parte- se do princípio de que a lógica dos sistemas de PSA é muito distinta daquela que predomina em nosso sistema normativo ambiental vigente, uma vez que as normas ambientais, em sua grande maioria, são baseadas em mecanismos de comando e controle. A lógica do PSA, ao contrário, não é pautada no estabelecimento de punição por atos prejudiciais ao meio ambiente, mas sim na busca de estímulo e contrapartidas financeiras a condutas ambientalmente desejáveis. Nesse sentido, os sistemas de Pagamento por Serviços Ambientais seriam uma inovação, se comparados aos sistemas de comando e controle, tendo como premissa não a internalização das externalidades negativas, mas das ações positivas; além do reconhecimento do valor social e econômico de atividades que proporcionem a conservação e uso sustentável dos ecossistemas e dos seus serviços.

Palavras-chave: Meio ambiente, Aspectos legais, Serviços ambientais

\section{ABSTRACT}

This article aims to analyze the concepts available and the main objectives of the institute called Payment for Environmental Services (PES) and Ecosystem, based on an analysis of the regulatory system and mapping key bills introduced in the Brazilian House of Representatives and the Senate, which deal about this subject. We intend to investigate whether the PES systems can be recognized as a valid environmental public policy, in line with the constitutional norms and the principles of environmental law, and if they can contribute in the conservation and sustainable use of ecosystems. Therefore, we start from the assumption that the PES systems logic is different from that which prevails in our current environmental regulatory system, since environmental standards are mostly based on command and control rules. The PES logic, in

\footnotetext{
${ }^{1}$ Mestre em Geografia pela Universidade Federal de Minas Gerais -UFMG, Belo Horizonte, Minas Gerais. Advogada pela Pontifícia Universidade Católica de Minas Gerais -PUC, Belo Horizonte, Minas Gerais, (Brasil) Email: tutortreinamento@gmail.com ${ }^{2}$ Especialização em Gestão Ambiental pela Universidade Flinders, Austrália Meridional, Austrália. Analista Ambiental
pelo Ministério do Meio Ambiente e da Amazônia Legal, Brasil.
} 
contrast, is not guided in setting punishment for harmful acts to the environment, but in the establishment of encouragement and financial

return to environmentally desirable behavior. In this sense, the systems of Payment for Environmental Services would be an innovation when compared to command and control systems, under the premise of not internalizing the negative externalities, but the positive actions; beyond the recognition of the social and economic value of activities that enable the conservation and sustainable use of ecosystems and their services.

Keywords: Environment, Legal aspects, Environmental services

\section{1 - INTRODUÇÃO}

O presente artigo tratará dos aspectos jurídicos pertinentes à prática de serviços ambientais ou ecossistêmicos ${ }^{1}$ no Brasil, identificando, para tanto, a conceituação, os fundamentos legais, as normas em vigor em nosso ordenamento jurídico que disponham sobre esses serviços, os projetos normativos em trâmite mais relevantes sobre o tema e algumas experiências verificadas no Brasil.

A relevância do assunto está relacionada com a própria importância da preservação e proteção do meio ambiente e da diversidade biológica, visto que nem todos os recursos naturais são renováveis e todos são finitos, sendo que já se pode perceber a escassez de alguns deles em nossas sociedades.

Nesse sentido, a manutenção da diversidade biológica constitui um serviço ambiental pelo qual muitos estão dispostos a pagar (Governos, investidores, Organizações NãoGovernamentais, entre outros), ao mesmo tempo em que outros (particulares) estão dispostos a receber.

Ademais, presenciamos um movimento de aumento do interesse e envolvimento das pessoas com a proteção do meio ambiente, e da construção gradativa de uma consciência coletiva no sentido de que a manutenção da biodiversidade, ao invés da sua exploração, pode constituir uma fonte de renda.

Ainda nesse sentido, verifica-se que ações de comando e controle, meramente coercitivas, não têm sido suficientes, ou eficientes para coibir a prática de ações/omissões que contribuem para a diminuição gradativa, e que podem inclusive levar ao extermínio de alguns ecossistemas brasileiros. De modo que políticas relacionadas ao pagamento por serviços ambientais são apontadas como uma opção viável para a melhoria da gestão do patrimônio ambiental.

As ações de comando e controle são baseadas no princípio do poluidor-pagador ${ }^{2}$, acolhido pela Lei federal 6938/1981, que dispõe sobre a Política Nacional de Meio Ambiente, 
1 A utilização da terminologia "serviços ecossistêmicos" é defendida por Édis Milaré (2013) como mais adequada, no lugar da expressão "serviços ambientais", emque pese essa segunda expressão haver se popularizado mais em nosso ordenamentojurídico. Adotaremos, no entanto, ao longo desse trabalho, a expressão mais difundida nas doutrinas, que seria "serviços ambientais".

${ }^{2}$ Art $4^{\circ}$ - A Política Nacional do Meio Ambiente visará: (...)VII - à imposição, ao poluidor e ao predador, da obrigação de recuperar e/ou indenizar os danos causados e, ao usuário, da contribuição pela utilização de recursos ambientais com fins econômicos. ( art. $4^{\circ}$, VII da Lei 6.938/1981, que dispõe sobre a Política Nacional do Meio Ambiente, seus fins e mecanis mos de formulação e aplicação, e dá outras providências.)

Art. 225. Todos têm direito ao meio ambiente ecologicamente equilibrado, bem de uso comum do povo e essencial à sadia qualidade de vida, impondo-se ao Poder Público e à coletividade o dever de defendê-lo e assim como pela Constituição Federal de 1988, segundo o qual o poluidor deverá ser responsabilizado pelos custos ambientais associados a sua atividade econômica. É a chamada internalização das externalidades negativas ou internalização dos prejuízos causados pela deterioração ambiental. $\mathrm{O}$ termo externalidades significa que, embora os efeitos negativos sejam resultantes de processos produtivos internos de determinadas atividades, eles acabam por ser percebidos externamente, por toda uma coletividade.

Segundo MILARÉ (2013), o termo externalidades é empregado para explicar os efeitos negativos ao meio ambiente, decorrentes de determinadas atividades econômicas, que são percebidos pela coletividade, ao contrário do lucro, que é percebido pelo produtor privado.

Assim, os custos sociais externos que acompanham o processo de produção deveriam ser internalizados; ou seja, os custos resultantes da poluição devem ser assumidos por aquele que empreende atividades potencialmente poluidoras. Mas, se ao invés de causar resultados negativos ao meio ambiente, determinada atividade trouxer resultados positivos, propiciando a conservação da biodiversidade?

Nesse caso, verifica-se uma inversão da lógica do princípio do poluidor-pagador, deixando entrever um novo princípio que seria o do protetor-recebedor, segundo o qual poderão ser internalizadas as externalidades positivas, reconhecendo-se o valor social e econômico de atividades que proporcionam a conservação e uso sustentável dos ecossistemas e dos seus serviços, bem como a importância de manutenção da biodiversidade.

Esse novo princípio, teria como principal objetivo, segundo MILARÉ (2013), evitar que o "custo-zero" dos serviços e recursos naturais acabe levando a um sistema mercadológico de exploração sem limites do meio ambiente. E para que se busque uma valoração do meio ambiente com mais efetividade, seria mais produtivo incentivar práticas positivas do que punir condutas danosas, por meio da aplicação de sanções que em grande parte das vezes não geram os efeitos esperados. 
Ou seja, ao invés de coibir a geração de externalidades negativas no processo produtivo, incentivar-se-iam as positivas por meio de normas promocionais. Seria como que uma consequência do princípio do poluidor-pagador, ou melhor, do usuário-pagador: aquele preserva ou recupera os serviços ambientais, geralmente de modo oneroso aos próprios interesses, tronar-se-ia credor de uma retribuição por parte dos beneficiários desses mesmos

preservá- lo para as presentes e futuras gerações. (...) $\S 3^{\circ}$ As condutas e atividades consideradas lesivas ao meio ambiente sujeitarão os infratores, pessoas físicas ou jurídicas, a sanções penais e administrativas, independentemente da obrigação de reparar os danos causados. (art. 225, § $3^{\circ}$ da Constituição Federal de 1988) serviços, sejam pessoas físicas ou jurídicas, seja o Estado ou a sociedade como um todo. (MILARÉ, 2013, p. 271)

A importância de se fomentar iniciativas de prestação de serviços para conservação da biodiversidade está, sobretudo, no fato dela possuir características únicas, não podendo ser substituída. Por exemplo, não há como reverter o processo de extinção de um espécime e/ou espécie. Assim, de modo a incentivar ações voltadas à proteção da biodiversidade e do meio ambiente, podem ser empregadas políticas de gratificação à preservação.

Partindo-se dessa premissa, iniciativas de remuneração por serviços ambientais estão se desenvolvendo no mundo inteiro, e não poderia ser diferente no Brasil. No caso brasileiro, o que se verifica é que ainda não foi promulgada uma norma federal que institua, em nível nacional e de forma sistematizada, uma política de serviços ambientais, com regras claras, aplicáveis em todo território brasileiro. Entretanto, normas e programas esparsos, em âmbito federal, estadual, e mesmo municipal, já apontam para o início de uma regulamentação do tema.

Ainda assim, a remuneração pela prática desses serviços ainda esbarra em limitações orçamentárias, sendo muitas vezes subjugada e reservada a segundo plano em razão de outras pautas consideradas prioritárias. Além do mais, há toda uma discussão principiológica quanto à correção e legalidade de se incentivar atividades de conservação ambiental, em troca de recompensa financeira, quando na verdade, como preceito constitucional, tanto o poder público quanto a coletividade têm o dever de prezar pelo meio ambiente equilibrado.

Por isso a importância de discussão e a formação de pesquisas consistentes sobre esse tema, bem como a regulamentação das suas bases principiológicas e conceituais por meio de normas específicas. Acredita-se, que a partir da regulamentação dessa prática, será mais fácil garantir um maior direcionamento de recursos públicos, bem como o desenvolvimento de políticas públicas destinadas à remuneração pelos serviços ambientais. 


\section{2 - DELINEANDO UM CONCEITO PARA O PAGAMENTO POR SERVIÇOS AMBIENTAIS}

Para se compreender o conceito desse instituto denominado Pagamento por Serviços Ambientais - PSA, terminologia que adotaremos neste artigo, deve-se partir da premissa de que serviços realizados em prol do meio ambiente remetem a externalidades positivas, ao contrário de ações que geram degradação ou poluição ambiental, o que nos remete a externalidades negativas. Segundo ALTMANN (2010), o reconhecimento da importância dos serviços ambientais por meio da sua valoração significaria a internalização das externalidades positivas.

Em um primeiro momento, esses serviços podem ser compreendidos como não passíveis de remuneração, já que as sociedades tendem a percebê-los como livres, providos gratuita e indefinidamente pelo meio ambiente aos homens. Ocorre que, para ALTMANN (2010), diante da constatação de que esses serviços podem se tornar escassos, e de que os mecanismos de comando e controle são insuficientes para garantir o seu provimento, alguns países passaram a adotar experiências de remuneração pela manutenção dos mesmos.

Ao tratar das primeiras iniciativas nesse sentido é inevitável mencionar a experiência da Costa Rica, país que acabou criando uma iniciativa pioneira de Pagamento por Serviços Ambientais, com a cobrança de uma taxa sobre o consumo de gasolina e de água, repassada aos proprietários que preservassem as florestas do país, medida que foi eficiente na diminuição do quadro de desmatamento local.

No modelo proposto pela Costa Rica foi criado um Programa de Pagos por Servicios Ambientales - PPSA, instrumento que possibilitou o pagamento direto a proprietários em escala nacional, contemplando três modalidades de uso da terra (conservação de florestas, reflorestamento e agrofloresta). Esse instrumento também levava em conta quatro tipos de serviços ambientais, tendo a compensação dirigida tanto a serviços individuais como a serviços coletivos.

Trata-se de um caso pioneiro na América Latina em que a experiência de Pagamento por Serviços Ambientais ganhou uma relevância muito grande, servindo de modelo para outros países. Observados os êxitos nesse programa proposto pela Costa Rica, passaram a tramitar no Brasil diversos projetos de lei propondo a instituição de uma política para o pagamento por esses serviços.

Além disso, em âmbito mundial, em 2005, com a publicação da Avaliação Ecossistêmica do Milênio ${ }^{3}$, foram lançados os resultados da primeira rodada de estudos, que 
duraram 4 (quatro) anos. Os estudos tiveram como foco o uso e depredação dos recursos naturais do planeta. Nele são definidos os serviços ecossistêmicos como os benefícios que o homem obtém da natureza e que são produzidos pelas interações que ocorrem no interior dos ecossistemas, divididos em serviços de provisão, de regulação, culturais e de suporte.

\footnotetext{
${ }^{3}$ Programa de pesquisas sobre mudanças ambientais e suas tendências para as próximas décadas. Foi lançado em 2001 com o apoio das Nações Unidas pelo Secretário Geral Kofi Annan. Disponível em \{http://www.ahpce.org.br/newsite/attachments/article/43/Sintese\%20Gera1\%20da\%20AM\%20(portugues).pdf \} Acesso em: 29/03/2015
}

É importante observar que no Brasil a expressão serviços ambientais ou ecossistêmicos vem sendo empregada, muitas vezes, em associação com a possibilidade de remuneração, para tratar de meios a serem empregados na preservação das funções ecológicas e da biodiversidade, como observa WALDMAN e ELIAS (2013):

O entendimento dado é o de que os indivíduos e coletividade protejam e preservem o meio ambiente a partir da transferência-recebimento de recursos financeiros ou outra espécie de retribuição pela atividade da fonte financiadora (pessoa física ou jurídica que tenha disposição a pagar, instituições governamentais, setor público, empresas privadas, doadores, organizações não governamentais, etc). (WALDMAN e ELIAS, 2013, p 56.)

Nesse sentido, o pagamento por serviços ambientais pode ser entendido como uma transação entre partes, sendo que uma delas, ao se beneficiar dos serviços prestados pelos ecossistemas, deve reconhecer o seu valor econômico e pagar pelos mesmos. Por outro lado, se houver outra parte envolvida, que se dedique a promover a conservação, recomposição, incremento ou manejo das funções ambientais de determinado ecossistema, de modo a possibilitar a manutenção desses serviços, ou mesmo se deixar de realizar práticas que possam provocar degradação ambiental com a cessação desses serviços, de forma voluntária; poderá fazer jus ao recebimento de remuneração.

Segundo MILARÉ (2013), há uma racionalidade fundamental por trás desse instrumento econômico, na medida em que aquele que recupera, viabiliza ou preserva os serviços ambientais, o faz geralmente de um modo oneroso aos seus próprios interesses, de modo que vem a se tornar credor de uma retribuição por parte de quem se beneficia desses serviços.

\footnotetext{
A lógica desse mecanismo, que se convencionou chamar de Pagamentos por Serviços Ambientais - PSA, consiste em aporte de incentivos e recursos, de origem pública e/ou privada, para aqueles que garantem a produção e a oferta do serviço e/ou produto obtido direta ou indiretamente da natureza. (MILARÉ, 2013, p. 271)
} 
E do outro lado, aquele que se beneficia da preservação de determinado serviço ambiental tende a ter disposição em pagar, uma vez que esse pagamento pode garantir o fluxo e a disponibilidade desses serviços.

ALTMANN (2010) aponta os requisitos caracterizadores do instituto do pagamento por serviços ambientais, que seriam a voluntariedade da transação, a adicionalidade e a necessidade de estabelecimento de parâmetros ou referências que indicarão a quantidade e qualidade do serviço ecológico a ser remunerado. Nesse lastro, ele conceitua o PSA como um contrato entre provedores e beneficiários, por meio do qual os beneficiários remuneram os provedores pelo fluxo contínuo de determinado serviço ambiental, com a intervenção do Estado para operacionalizar o sistema, garantindo o cumprimento dos contratos.

Para ALTMANN (2010), a lógica de se pagar pelos benefícios obtidos dos ecossistemas foi percebida pioneiramente no Brasil no texto da Política Nacional dos Recursos Hídricos (Lei federal $n^{\circ}$ 9.433/97), na instituição da cobrança pelo uso da água ${ }^{4}$.

Em que pese já ser possível observar algumas iniciativas de instituição de pagamento por serviços ambientais em normas vigentes no Brasil, ainda não é possível verificar em nosso ordenamento a existência de uma norma que institua uma ampla regulamentação desse instituto. Além disso, é possível verificar, na doutrina, algumas análises formuladas sobre o tema.

Para NUSDEO (2012), há cinco características que definiriam o Pagamento por Serviços Ambientais:

a) serem as transações voluntárias; b) ser bem definido o serviço ou, ao menos, determinado uso da terra tido como necessário para provê-lo; c) a existência de, ao menos, um comprador; d) a existência de pelo menos um provedor e e) ser o pagamento condicionado à provisão do serviço. (NUSDEO, 2012, p. 138)

É importante observar atentamente as características defendidas pela autora, sobretudo aquela que concerne à necessidade das transações serem voluntárias, uma vez que o aspecto da voluntariedade ainda é bastante discutido, mas a nosso ver seria indispensável, na medida em que não parece sensato classificar como serviços ambientais passíveis de pagamento aquelas ações que já seriam oponíveis em virtude de previsão legal, ou que sejam impostas a determinado agente, a título exemplificativo, por força de condicionante de licença

\footnotetext{
${ }^{4}$ Instrumento econômico de gestão das águas previsto na Política Nacional de Recursos Hídricos. A Cobrança visa ao reconhecimentoda água como um bem ecológico, social e econômico, dando ao usuário uma indicação de seu real valor. No entanto, não se trata de taxa ou imposto, mas sim de um preço público e visa incentivar os usuários a utilizarem a água de forma mais racional, garantindo, dessaforma,oseu uso múltiplo para as atuais e futuras gerações. Objetiva também arrecadar recursos financeiros para o financiamento de programas e intervenções previstos no Plano Diret or de Recursos Hídricos da Bacia Hidrográfica, volt ados para a melhoria da quantidade e daqualidadeda água.
} 
ambiental, ou de obrigação assumida em termos de ajustamento de conduta, entre outras formas de imposição que possam ser verificadas.

O autor Édis Milaré (2013) entende o PSA como um instrumento econômico normativo, nesses termos:

Trata-se assim, de um instrumento econômico normativo destinado a dirigir e estimular comportamentos para a consecução do objetivo (jurídico, político e econômico) pré-estabelecido de garantir a preservação dos processos ecológicos essenciais por meio da remuneração do conservador, provedor e/ou viabilizador. (MILARÉ, 2013, pag. 128)

Outros autores também se aventuraram no conceito desse instituto, como é o caso de WALDMAN e ELIAS (2013), segundo os quais, entre as definições doutrinárias existentes, as mais aceitas seriam:

(...) transação voluntária (acordo formal ou contrato de prestação de serviços entre provedores e beneficiários), por meio da qual um serviço ecológico específico ou um uso da natureza e tecnologia que possa assegurá-lo, é adquirido por um ou mais adquirentes de um ou mais provedores se, e somente se, este garantir sua provisão (condicionalmente). (WALDMAN e ELIAS, 2013, p. 57)

Além de investigar o conceito, esses autores alertam para o fato de que antes de se implementar um sistema PSA, é recomendável comparar os benefícios que podem ser gerados aos seus custos de implantação. Outro aspecto advertido é a possibilidade de que o pagamento não se restrinja a pecúnia, podendo ser realizado na forma de isenções fiscais, benfeitorias, acesso facilitado ao mercado, programas especiais e concessão de linhas de crédito, disponibilização de tecnologias, capacitação, entre outros.

Ainda tratando sobre a valoração e remuneração de atividades dessa natureza, WALDMAN e ELIAS (2013) mencionam a dificuldade de valoração financeira de um serviço ambiental devido à subjetividade dos parâmetros envolvidos, e pelo fato do custo ambiental não encontrar valoração pecuniária correspondente, em razão do pagamento estar direcionado a um bem intangível. E entre os entraves legais, os autores mencionam a dificuldade de recepção desse conceito no Direito Ambiental brasileiro, uma vez que acabaria ocasionando uma alteração significativa de preceitos já consolidados.

Os preceitos consolidados, tal como mencionado pelo autor, referem-se principalmente a valores e a princípios do Direito Ambiental brasileiro, que se refletem em grande parte das normas ambientais vigentes, já bastante disseminados, tal como o já 
mencionado princípio do poluidor-pagador, prenunciado no Princípio 16 da Declaração do Rio sobre Meio Ambiente e Desenvolvimento ${ }^{5}$ e consolidado na Constituição de 1988.

Diante da análise dos autores citados, que trazem importantes reflexões sobre o conceito do instituto de pagamento por serviços ambientais, é possível verificar que, em que pese não haver, em âmbito nacional, uma norma em vigor que institua e regulamente uma política de pagamento por serviços ambientais, já há alguma convergência conceitual, seja em projetos de lei, seja em trabalhos acadêmicos formulados sobre o tema, acerca do conceito do Pagamento por Serviços Ambientais.

Partindo do aparato conceitual ora avaliado, procederemos a seguir a uma análise do conteúdo de algumas normas existentes em nosso sistema jurídico, que ainda de forma um pouco incipiente, já dispõem sobre mecanismos que refletem a intenção de se possibilitar o Pagamento por Serviços Ambientais no Brasil.

\section{3 - NORMAS FEDERAIS, ESTADUAIS E MUNICIPAIS QUE DISPÕEM SOBRE SERVIÇOS AMBIENTAIS NO ORDENAMENTO JURÍDICO BRASILEIRO}

SANTOS, BRITO, MASCHIETTO, OSÓRIO e MONZONI (2012) corroboram com o entendimento exposto nos itens anteriores, de que o ordenamento jurídico brasileiro ainda não dispõe de norma geral que institua uma Política Nacional de Pagamento por Serviços Ambientais - PNPSA e fixe uma padronização do sistema de pagamento por esses serviços, ou seja, não há ainda um marco legal federal sobre PSA.

Até o presente momento, verifica-se a existência de algumas normas dispersas que tratam indiretamente sobre o tema, além de diversos projetos normativos acerca do assunto que se encontram em tramitação tanto perante a Câmara dos Deputados quanto perante o Senado Federal, o que será objeto de uma breve análise a seguir.

\section{1 - DISPOSITIVOS LEGAIS FEDERAIS}

Em âmbito federal, como exemplo de regulamentação existente acerca de serviços ambientais, deve-se primeiramente atentar para a previsão da Lei federal $\mathrm{n}^{\circ}$ 6.938/81, popularmente conhecida como a Política Nacional de Meio Ambiente, que enumera, entre os

\footnotetext{
${ }^{5}$ Princípio 16: As autoridades nacionais devem procurar promover a internacionalização dos custos ambientais e o uso de instrumentos econômicos, tendo em vista a abordagem segundo a qual o poluidor deve, em princípio, arcar com o custo da poluição, com a devida atenção ao interesse público e sem provocar distorções no comércio e nos investimentos internacionais.
} 
seus princípios, a concessão de incentivos ao estudo e à pesquisa de tecnologias orientadas para o uso racional e a proteção dos recursos ambientais, nos termos do art. $2^{\circ}$, inciso $\mathrm{VI}^{6}$.

$\mathrm{O}$ art. $9^{\circ}$, inciso $\mathrm{V}^{7}$ da referida norma dispõe ainda que os incentivos à produção e instalação de equipamentos e a criação ou absorção de tecnologia, voltados para a melhoria da qualidade ambiental, constituem instrumentos da Política Nacional do Meio Ambiente. Por outro lado, o art. 14 , inciso II $^{8}$ prevê que em caso de infrações, com a respectiva aplicação das penalidades definidas pela legislação ambiental, o não cumprimento das medidas necessárias à preservação ou correção dos inconvenientes e danos causados pela degradação da qualidade ambiental sujeitará os transgressores à perda ou restrição de incentivos e benefícios fiscais concedidos pelo Poder Público.

A seu turno, o novo Código Florestal (Lei Federal $n^{\circ}$ 12.651/12), em seu artigo $41^{9}$, autoriza o Poder Executivo federal a instituir programa de apoio e incentivo à conservação do meio ambiente, bem como a incentivar a adoção de tecnologias e boas práticas que conciliem a produtividade agropecuária e florestal, com redução dos impactos ambientais, como forma de promoção do desenvolvimento ecologicamente sustentável, observados os critérios de progressividade.

Acredita-se que o artigo 41 da Lei Federal $n^{\circ}$ 12.651/ 2012 foi inserido com o objetivo de justamente direcionar parte dos gastos públicos para a proteção e preservação do meio ambiente, mediante a remuneração de serviços ambientais, enquanto política pública. $\mathrm{O}$ dispositivo legal citado ainda depende de regulamentação federal, mas a discussão já foi lançada e já é possível observar exemplos práticos, em todo território brasileiro, de remuneração de particulares pela prática de serviços ambientais, como buscaremos investigar ao longo do presente artigo.

\footnotetext{
${ }^{6}$ Art. $2^{\circ}$. A Política Nacional do Meio Ambiente tem por objetivo a preservação, melhoria e recuperação da qualidade ambiental propícia à vida, vis ando as segurar, no País, condições ao desenvolvimento sócioeconômico, autoriza aos interesses da segurança nacional e à proteção da dignidade da vida humana, atendidos os seguintes princípios: (...) VI - incentivos ao estudo e à pesquisa de tecnologias orientadas para o uso racional e a proteção dos recursos ambientais;

7 Art. $9^{\circ}$ - São Instrumentos da Política Nacional do Meio Ambiente: (...)V - os incentivos à produção e instalação de equipamentos e a criação ou absorção de tecnologia, voltados para a melhoria da qualidade ambiental;

8 Art. 14 - Sem prejuízo das penalidades definidas pela legislação federal, estadual e municipal, o não cumprimento das medidas necessárias à preservação ou correção dos inconvenientes e danos causados pela degradação da qualidade ambiental sujeitará os transgressores: (...) II - à perda ou restrição de incentivos e benefícios fiscais concedidos pelo Poder Público;

9 Art. 41. É o Poder Executivo federal autorizado a instituir, sem prejuízo do cumprimento da legislação ambiental, programa de apoio e incentivo à conservação do meio ambiente, bem como para adoção de tecnologias e boas práticas que conciliem a produtividade agropecuária e florestal, com redução dos impactos ambientais, como forma de promoção do desenvolvimento ecologicamente sustentável, observados sempre os critérios de progressividade, abrangendo as seguintes categorias e linhas de ação: (Redação dada pela Lei $\mathrm{n}^{\circ}$ 12.727, de 2012).
} 
Conforme sustentam MILARÉ e MACHADO (2012), o programa de apoio à conservação do meio ambiente, introduzido no ordenamento jurídico brasileiro pelo novo Código Florestal constitui instrumento econômico normativo destinado a dirigir e a estimular comportamentos para a consecução do objetivo (jurídico, político e econômico) preestabelecido de garantir a preservação do meio ambiente por meio da remuneração do conservador, provedor e/ou viabilizador.

Por sua vez, a Lei federal $\mathrm{n}^{\mathrm{o}}$ 12.305/10, que institui a Política Nacional de Resíduos Sólidos - PNRS, classifica a concessão de incentivos fiscais, financeiros e creditícios como um de seus instrumentos, conforme consta do art. $8^{\circ}$, inciso $\mathrm{IX}^{10}$. Esses incentivos poderão ser concedidos, por exemplo, na hipótese prevista no parágrafo único do art. $35^{11}$ da mesma norma, que faz referência à concessão de incentivos econômicos pelo poder público municipal aos consumidores que participam do sistema de coleta seletiva, na forma de lei municipal.

Ademais, o art. $44^{12}$ da Lei $n^{\circ} 12.305 / 10$ estabelece que a União, os Estados, o Distrito Federal e os Municípios, no âmbito de suas competências, poderão instituir normas com o objetivo de conceder incentivos fiscais, financeiros ou creditícios, respeitadas as limitações previstas na Lei Complementar no 101/00 (Lei de Responsabilidade Fiscal).

Além dos dispositivos legais mencionados, a Lei Federal $n^{\circ} 9.985 / 00$, que institui o Sistema Nacional de Unidades de Conservação da Natureza - SNUC, também aborda o tema, nos termos do art. $4^{\circ}$, inciso $\mathrm{XI}^{13}$. A norma estabelece que um dos objetivos do SNUC é justamente valorizar econômica e socialmente a diversidade biológica, possuindo como diretriz a possiblidade de concessão de incentivos às populações locais e organizações privadas que estabelecerem e administrarem unidades de conservação dentro do sistema nacional.

Acrescente-se a isso o disposto na Lei Federal $n^{\circ} 12.114 / 09$, que cria o Fundo Nacional sobre Mudança do Clima, a qual prevê em seu art. $5^{\circ}, \S 4^{\circ}$, incisos IX e XI ${ }^{14}$, a

\footnotetext{
${ }^{10}$ Art. $8^{\circ}$ São instrumentos da Política Nacional de Resíduos Sólidos, entre outros: (...)IX - os incentivos fiscais, financeiros e creditícios;

${ }^{11}$ Art. 35. Sempre que estabelecido sistema de coleta seletiva pelo plano municipal de gestão integrada de resíduos sólidos e na aplicação do art. 33, os consumidores são obrigados a: (...)Parágrafo único. O poder público municipal pode instituir incentivos econômicos aos consumidores que participam do sistema de coleta seletiva referido no caput, na forma de lei municipal.

${ }^{12}$ Art. 44. A União, os Estados, o Distrito Federal e os Municípios, no âmbito de suas competências, poderão instituir normas com o objetivo de conceder incentivos fiscais, financeiros ou creditícios, respeitadas as limitações da Lei Complementar no 101, de 4 de maio de 2000 (Lei de Responsabilidade Fiscal), a:

${ }^{13}$ Art. $4^{\circ}$ O SNUC tem os seguintes objetivos:(...) XI - valorizar econômica e socialmente a diversidade biológica;

${ }^{14}$ Art. $5^{\circ}$ Os recursos do FNMC serão aplicados: (...)§ $4^{\circ} \mathrm{A}$ aplicação dos recursos poderá ser destinada às seguintes atividades: IX - desenvolvimento de produtos e serviços que contribuam para a dinâmica de
} 
possibilidade de aplicação de parte dos recursos oriundos do Fundo em desenvolvimento de produtos e serviços que contribuam para a conservação ambiental e estabilização da concentração de gases de efeito estufa, bem como em pagamentos por serviços ambientais às comunidades e indivíduos cujas atividades contribuam para a estocagem de carbono, atrelada a outros serviços ambientais.

Por fim, importante mencionar o recente Estatuto da Metrópole (Lei Federal 13.089/15), que apesar de não detalhar propostas de compensação por serviços ambientais, acaba apontando algumas possibilidades para sua aplicação como estratégia de integração urbana sustentável.

Ainda em nível federal, o Brasil possui algumas iniciativas de remuneração por serviços ambientais. Um exemplo é o Programa de Desenvolvimento Socioambiental de Produção Familiar Rural - PROAMBIENTE do Ministério do Meio Ambiente, que paga 1/3 de salário mínimo aos agricultores e pecuaristas que empregam técnicas menos nocivas ao meio ambiente, como a não utilização de agrotóxicos ou a execução de sistemas agroflorestais.

\section{2 - DISPOSITIVOS LEGAIS ESTADUAIS}

Apesar da inexistência de um marco legal federal; conforme explicam SANTOS, BRITO, MASCHIETTO, OSÓRIO e MONZONI (2012); a partir de levantamento efetuado pelo IMAZON e pela Fundação Getúlio Vargas - FGV (2012), verificou-se que diversos estados brasileiros elaboraram suas legislações e programas locais de PSA. Estados como Acre, Amazonas, Espírito Santo, Minas Gerais, Paraná, Rio de Janeiro, Santa Catarina e São Paulo possuem normas estaduais que disciplinam o Pagamento por Serviços Ambientais diante de situações específicas.

Tome-se como exemplo a Bolsa Verde, instituída em Minas Gerais por meio da Lei estadual $n^{\circ} 17.727 / 08$ e regulamentada pelo Decreto $n^{\circ} 45.113 / 09$, que constitui incentivo financeiro a proprietários e posseiros rurais, para identificação, recuperação, preservação e conservação de áreas necessárias à proteção das formações ciliares e à recarga de aquíferos, e áreas necessárias à proteção da biodiversidade e ecossistemas especialmente sensíveis, conforme regulamento.

conservação ambiental e estabilização da concentração de gases de efeito estufa; XI - pagamentos por serviços ambientais às comunidades e aos indivíduos cujas atividades comprovadamente contribuam para a estocagem de carbono, atrelada a outros serviços ambientais; 
Outro exemplo relevante é a Lei no 3.135/07 do Estado da Amazônia, que institui a Política Estadual sobre Mudanças Climáticas, Conservação Ambiental e Desenvolvimento Sustentável do estado, com o objetivo de estimular os modelos regionais de desenvolvimento sustentável do Amazonas, mediante incentivos de natureza financeira e não financeira; assim como de orientar, fomentar e regular, no âmbito estadual, a operacionalização do Mecanismo de Desenvolvimento Limpo - MDL e de outros projetos de redução das emissões de gases de efeito estufa e/ou de redução de emissões de desmatamento - RED dentro do estado.

Ainda em nível estadual, o governo do Amazonas criou, em 2007, o "Bolsa Floresta", pago às familias de ribeirinhos e às comunidades tradicionais que vivem no entorno ou dentro de unidades de conservação estaduais. Além disso, alguns estados criaram o ICMS ecológico, em que aplicam parte da arrecadação do imposto em projetos de preservação ambiental.

\section{3 - DISPOSITIVOS LEGAIS MUNICIPAIS}

De acordo com OLIVEIRA JÚNIOR (2010), além dos estados, diversos municípios brasileiros vêm formulando legislações que criam condições de financiamento ou o pagamento aos prestadores de serviços ambientais. São exemplos a Lei 2.100/2005, de Extrema (MG), instituindo o projeto Conservador das Águas; a Lei 3.545/2006, de Montes Claros (MG), criando o Ecocrédito; a Lei 58/2009, criando o Projeto Oásis em Apucarana (PR); e a Lei 14.933/2009, em São Paulo (SP), prevendo recursos para serviços ambientais.

Ainda como exemplo vale mencionar o Plano Diretor da Cidade de São Paulo (Lei municipal 16.050/14), que consolida uma estratégia inovadora de compensação por serviços ambientais.

O artigo 71 da referida lei municipal prevê a aplicação de dois mecanismos de compensação: a transferência do potencial construtivo e o pagamento por serviços ambientais. O primeiro já bastante disseminado na legislação urbanística. O segundo, no entanto, ainda não contava com previsão legal tão detalhada. O programa municipal de PSA previsto na norma poderá beneficiar proprietários ou possuidores que mantenham, restabeleçam ou recuperem áreas com ecossistemas provedores de serviços ambientais.

Contudo, mesmo diante da existência de normas que instituem mecanismo de PSA nos âmbitos federal, estadual e municipal, como exemplificado, ainda assim o ordenamento jurídico brasileiro carece de uma regulamentação que institua uma Política Nacional de 
Pagamento por Serviços Ambientais com o objetivo de estabelecer uma padronização das iniciativas já observadas e, ao mesmo tempo, garantir segurança jurídica às partes envolvidas e à sociedade.

\section{4 - BREVE SISTEMATIZAÇÃO DE PROJETOS NORMATIVOS RELEVANTES SOBRE O TEMA EM ÂMBITO FEDERAL}

Nos itens anteriores, por meio de uma breve análise das normas em vigor no ordenamento jurídico brasileiro, buscamos ampliar a compreensão dos conceitos de serviços ambientais e pagamentos por serviços ambientais.

Nessa próxima fase buscaremos sistematizar o conteúdo de alguns projetos de lei existentes no âmbito federal, que têm como objetivo a instituição de uma Política de Pagamento por Serviços Ambientais.

Além dos projetos existentes no âmbito federal, alguns estados brasileiros já possuem normas e outros projetos de lei dispondo sobre pagamento por serviços ambientais, tais como o Acre, Amazonas, Espírito Santo, Minas Gerais, São Paulo, Rio de Janeiro, Santa Catarina e Paraná, possuem projetos de lei sobre o tema.

O Instituto do Homem e Meio Ambiente da Amazônia - IMAZON e o Centro de Estudos em Sustentabilidade da Fundação Getúlio Vargas conduziram um estudo acerca do marco regulatório sobre PSA no Brasil, que englobou a análise das normas existentes nesses estados, além de projetos de lei em tramitação.

A análise foi realizada com base em nove componentes considerados essenciais para o regime jurídico de PSA, quais sejam: arranjo institucional, tipos de serviços ambientais abrangidos, fontes de recursos, beneficiários, categorias fundiárias elegíveis para os programas, requisitos de acesso ao recebimento de benefício, remuneração e critério de cálculo, sistemas de verificação de prestação dos serviços e salvaguardas socioambientais.

Conforme divulgado pelo IMAZON, a maioria das normas e projetos de lei analisados prevê apoio a serviços ambientais de forma ampla, com algumas exceções mais direcionadas a sequestro ou conservação de estoque de carbono. Os beneficiários mais frequentemente citados são os proprietários e possuidores de terra, agricultores familiares e assentados, bem como comunidades tradicionais e povos indígenas. 
As fontes de recursos previstas nas normas são variadas, com predominância de orçamento público e fundos estaduais; havendo ainda previsão de doações, acordos e instrumentos similares, provenientes de fontes nacionais ou internacionais.

Uma das recomendações do relatório final produzido pelo IMAZON foi a necessidade de construção de uma lei federal sobre PSA que leve em conta as lições aprendidas com as normas estaduais existentes, consolidando experiências positivas para criação de conceitos, princípios e fontes orçamentárias para iniciativas de PSA em todo o território brasileiro.

A partir dessas recomendações, e por concordar que existe uma brecha legal a ser preenchida, buscamos, a seguir, sistematizar os principais projetos de lei propostos pela Câmara dos Deputados e pelo Senado Federal acerca do pagamento por serviços ambientais.

\begin{tabular}{|c|c|c|c|c|}
\hline Proje to Lei & Casa Legislativa & Assunto & Propositura & Des pacho atual \\
\hline $5974 / 2005$ & $\begin{array}{l}\text { Câmara dos } \\
\text { Deputados }\end{array}$ & $\begin{array}{l}\text { Dispõe sobre incentivos fiscais } \\
\text { para projetos ambientais. }\end{array}$ & $29 / 09 / 2005$ & $\begin{array}{l}\text { Às Comissões de } \\
\text { Meio Ambiente e } \\
\text { Desenvolvimento } \\
\text { Sustentável, } \\
\text { Finanças } \\
\text { Tributação em } \\
10 / 10 / 2005\end{array}$ \\
\hline $792 / 2007$ & $\begin{array}{ll}\text { Câmara } & \text { dos } \\
\text { Deputados } & \end{array}$ & $\begin{array}{l}\text { Dispõe sobre a definição de } \\
\text { serviços ambientais e dá outras } \\
\text { providências }\end{array}$ & $19 / 04 / 2007$ & $\begin{array}{l}\text { Aprovado } \\
\text { requerimento em } \\
\text { 10/06/2015 do Sr. } \\
\text { Evair de Melo para } \\
\text { realização r de } \\
\text { Audiência Pública } \\
\text { para debater os } \\
\text { Estudos de casos } \\
\text { de projetos já } \\
\text { implantados de } \\
\text { PSA no Projeto de } \\
\text { Lei n } \text { n }^{\circ} \text { 792, de } \\
2007\end{array}$ \\
\hline $1190 / 2007$ & $\begin{array}{ll}\text { Câmara } & \text { dos } \\
\text { Deputados } & \end{array}$ & $\begin{array}{l}\text { Cria o Programa Nacional de } \\
\text { Compensação por Serviços } \\
\text { Ambientais - Programa Bolsa } \\
\text { Verde, destinado à } \\
\text { transferência de renda aos } \\
\text { agricultores familiares, com } \\
\text { condicionalidades. }\end{array}$ & $29 / 05 / 2007$ & $\begin{array}{lll}\text { Apense-se } & \text { ao } & \text { PL } \\
792 / 2007 & \text { em } \\
08 / 06 / 2007 & \end{array}$ \\
\hline
\end{tabular}




\begin{tabular}{|c|c|c|c|c|}
\hline $6204 / 2009$ & $\begin{array}{ll}\text { Câmara } & \text { dos } \\
\text { Deputados } & \end{array}$ & $\begin{array}{l}\text { Cria os comitês municipais } \\
\text { para gestão dos recursos do } \\
\text { Fundo Nacional de Meio } \\
\text { Ambiente para pagamento ao } \\
\text { produtor rural por serviços } \\
\text { ambientais. }\end{array}$ & $13 / 10 / 2009$ & $\begin{array}{lll}\text { Apense-se } & \text { ao } & \text { PL } \\
792 / 2007 & & \text { em } \\
21 / 10 / 2009 & & \end{array}$ \\
\hline $5487 / 2009$ & $\begin{array}{ll}\text { Câmara } & \text { dos } \\
\text { Deputados } & \end{array}$ & $\begin{array}{l}\text { Institui a Política Nacional dos } \\
\text { Serviços Ambientais, o } \\
\text { Programa Federal de } \\
\text { Pagamento por Serviços } \\
\text { Ambientais, estabelece formas } \\
\text { de controle e financiamento } \\
\text { desse Programa, e dá outras } \\
\text { providências. }\end{array}$ & $24 / 06 / 2009$ & $\begin{array}{lr}\text { Apense-se } & \text { ao } \\
\text { PL792/2007 } & \text { em } \\
01 / 07 / 2009 & \end{array}$ \\
\hline $7224 / 2010$ & $\begin{array}{ll}\text { Câmara } & \text { dos } \\
\text { Deputados } & \end{array}$ & $\begin{array}{l}\text { Concede incentivo fiscal do } \\
\text { Imposto sobre a Renda às } \\
\text { pessoas físicas ou jurídicas que } \\
\text { implantarem projetos de } \\
\text { reflorestamento e florestamento } \\
\text { e de preservação do meio } \\
\text { ambiente. }\end{array}$ & $29 / 04 / 2010$ & $\begin{array}{lrr}\text { Apense-se } & \text { ao } & \text { PL } \\
5974 / 2005 & & \text { em } \\
12 / 05 / 2010 & & \end{array}$ \\
\hline $1428 / 2011$ & $\begin{array}{ll}\text { Câmara } & \text { dos } \\
\text { Deputados } & \end{array}$ & $\begin{array}{l}\text { Institui benefício fiscal a } \\
\text { empresas que apresentem } \\
\text { projetos de conservação e } \\
\text { proteção de parques de alta } \\
\text { relevância ambiental } \\
\text { previamente aprovados pelo } \\
\text { Ministério do Meio Ambiente. }\end{array}$ & $24 / 05 / 2011$ & $\begin{array}{lll}\text { Apense-se } & \text { ao } & \text { PL } \\
7224 / 2010 & & \text { em } \\
01 / 06 / 2011 & & \end{array}$ \\
\hline $1274 / 2011$ & $\begin{array}{ll}\text { Câmara } & \text { dos } \\
\text { Deputados } & \end{array}$ & $\begin{array}{l}\text { Institui o Programa Nacional } \\
\text { de Compensação por Serviços } \\
\text { Ambientais e dá outras } \\
\text { providências. }\end{array}$ & $10 / 05 / 2011$ & $\begin{array}{l}\text { Às Comissões de } \\
\text { Agricultura, } \\
\text { Pecuária, } \\
\text { Abastecimento e } \\
\text { Desenvolvimento } \\
\text { Rural; } \\
\text { Meio Ambiente e } \\
\text { Desenvolvimento } \\
\text { Sustentável; } \\
\text { Finanças } \\
\text { Tributação e } \\
\text { Constituição e } \\
\text { Justiça e de } \\
\text { Cidadania em } \\
\text { 23/05/2011 em }\end{array}$ \\
\hline $6146 / 2013$ & $\begin{array}{ll}\text { Câmara } & \text { dos } \\
\text { Deputados } & \end{array}$ & $\begin{array}{l}\text { Dispõe sobre incentivos fiscais } \\
\text { para projetos ambientais. }\end{array}$ & $21 / 08 / 2013$ & $\begin{array}{lrr}\text { Apense-se } & \text { ao } & \text { PL } \\
5974 / 2005 & & \text { em }\end{array}$ \\
\hline
\end{tabular}




\begin{tabular}{|c|c|c|c|c|}
\hline & & & & $02 / 09 / 2013$ \\
\hline $312 / 2015$ & $\begin{array}{l}\text { Câmara dos } \\
\text { Deputados }\end{array}$ & $\begin{array}{l}\text { Institui a Política Nacional de } \\
\text { Pagamento por Serviços } \\
\text { Ambientais e dá outras } \\
\text { providências. }\end{array}$ & $10 / 02 / 2015$ & $\begin{array}{lr}\text { Encaminhado } & \text { em } \\
\text { 26/02/2015 às } & \text { àn } \\
\text { Comissões } & \text { de } \\
\text { Agricultura, } & \\
\text { Pecuária, } & \\
\text { Abastecimento } & \text { e } \\
\text { Desenvolvimento } & \\
\text { Rural; } & \text { Meio } \\
\text { Ambiente } & \text { e } \\
\text { Desenvolvimento } & \\
\text { Sustentável; } & \\
\text { Finanças } & \text { e } \\
\text { Tributação } & \text { e } \\
\text { Constituição } & \text { e } \\
\text { Justiça e } & \text { de } \\
\text { Cidadania } & \end{array}$ \\
\hline $1465 / 2015$ & $\begin{array}{l}\text { Câmara dos } \\
\text { Deputados }\end{array}$ & $\begin{array}{l}\text { Cria incentivos fiscais e } \\
\text { creditícios a pessoas físicas e } \\
\text { jurídicas que promovam a } \\
\text { reposição florestal ou } \\
\text { desassoreamento de rios, } \\
\text { córregos, cursos de água ou } \\
\text { nascentes e dá outras } \\
\text { providências. }\end{array}$ & $07 / 05 / 2015$ & 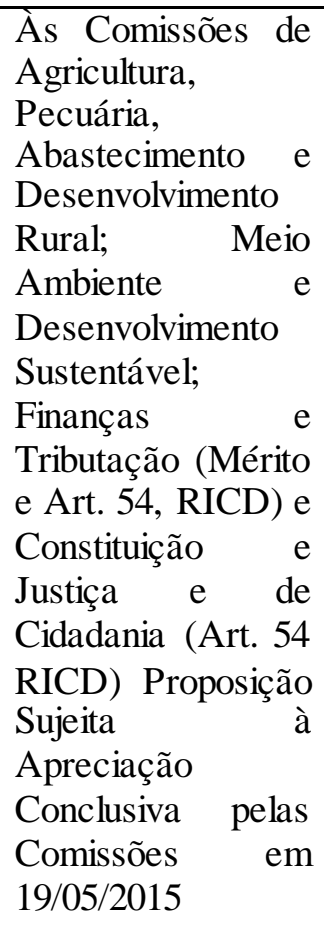 \\
\hline $142 / 2007$ & Senado & $\begin{array}{l}\text { Acrescenta inciso aos artigos } \\
21,22 \text { e } 38 \text { da Lei no 9.433, de } \\
08 \text { de janeiro de 1997, para } \\
\text { estabelecer retribuição por } \\
\text { serviços ambientais decorrentes } \\
\text { de boas práticas rurais que } \\
\text { resultem na maior } \\
\text { disponibilidade de água em } \\
\text { quantidade e qualidade nas } \\
\text { bacias hidrográficas. }\end{array}$ & & \\
\hline $212 / 2011$ & Senado & $\begin{array}{l}\text { Institui o sistema nacional de } \\
\text { redução de emissões por }\end{array}$ & $03 / 05 / 2011$ & $\begin{array}{l}\text { A presente } \\
\text { proposição }\end{array}$ \\
\hline
\end{tabular}




\begin{tabular}{|c|c|c|c|c|}
\hline & & $\begin{array}{l}\text { desmatamento e degradação, } \\
\text { conservação, manejo florestal } \\
\text { sustentável, manutenção e } \\
\text { aumento dos estoques de } \\
\text { carbono florestal (REDD+), e } \\
\text { dá outras providências. }\end{array}$ & & $\begin{array}{l}\text { continua } \\
\text { tramitar, } \\
\text { 17/12/2014, nos } \\
\text { termos dos incisos } \\
\text { do art. 332 do } \\
\text { Regimento Interno } \\
\text { e do Ato da Mesa } \\
\mathrm{n}^{\mathbf{o}} 2 \text { de } 2014\end{array}$ \\
\hline $155 / 2012$ & Senado & $\begin{array}{l}\text { Destina recursos ao Fundo } \\
\text { Nacional de Meio Ambiente, } \\
\text { instituído pela Lei no } 7.797, \text { de } \\
10 \text { de julho de } 1989 \text {, para o } \\
\text { pagamento por serviços } \\
\text { ambientais e para a } \\
\text { recomposição da cobertura } \\
\text { vegetal em áreas de } \\
\text { preservação permanente } \\
\text { ripárias. }\end{array}$ & $15 / 05 / 2012$ & $\begin{array}{lr}\text { A } & \text { presente } \\
\text { proposição } & \\
\text { continua } & \text { a } \\
\text { tramitar, } & \text { nos } \\
\text { termos } & \text { dos } \\
\text { incisos do } & \text { art. } \\
332 & \text { do } \\
\text { Regimento } & \\
\text { Interno e } & \text { do } \\
\text { Ato da } & \text { Mesa no } \\
2 \text { de } 2014, & \text { em } \\
17 / 12 / 2014 & \end{array}$ \\
\hline $276 / 2013$ & Senado & $\begin{array}{l}\text { Institui a Política Nacional de } \\
\text { Pagamento por Serviços } \\
\text { Ambientais (PNPSA) }\end{array}$ & $04 / 07 / 2013$ & 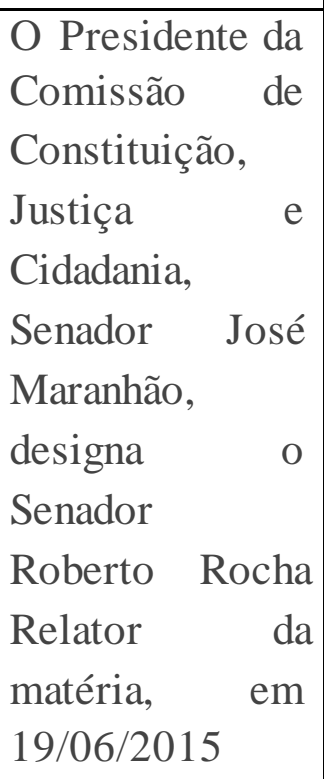 \\
\hline
\end{tabular}

O que pode ser observado são algumas iniciativas de projetos de lei que intencionam promover a sistematização e regulamentação do tema. O Projeto de Lei PL 5487/2009 da Câmara de Deputados, apensado ao PL 792/2007, apresentado em 5 de junho de 2009, institui a Política Nacional dos Serviços Ambientais e o Programa 
Federal de Pagamento por Serviços Ambientais, estabelecendo formas de controle e financiamento para esse Programa.

$\mathrm{O}$ referido PL preceitua que ao conceber o meio ambiente como prestador de serviços ambientais é possível inseri-lo aos processos econômico, produtivo, social e cultural; superando uma concepção ultrapassada do meio ambiente como mero fornecedor de matériaprima e receptor de resíduos.

Nesse passo, o citado Projeto de Lei conceitua os serviços ambientais como os serviços desempenhados pelo meio ambiente que resultem em condições adequadas à sadia qualidade de vida, o que pode se dar nas seguintes modalidades: serviços de aprovisionamento, de suporte e regulação e serviços culturais.

O mesmo Projeto de Lei conceitua o PSA como a retribuição, monetária ou não, às atividades humanas de restabelecimento, recuperação, manutenção e melhoria dos ecossistemas que geram serviços ambientais e que estejam amparados por planos e programas específicos; sendo o pagador aquele que provê o pagamento dos serviços, e recebedor aquele que restabelece, recupera, mantém ou melhora os ecossistemas no âmbito desses planos e programas específicos.

Nos moldes do mencionado PL n $5.487 / 2009$, os serviços ambientais apresentam-se sob as modalidades abaixo listadas:

Art. $2^{\circ}$ Para os fins desta Lei, consideram-se:

a) serviços de aprovisionamento: serviços que resultam em bens ou produtos ambientais com valor econômico, obtidos diretamente pelo uso e manejo sustentável dos ecossistemas;

b) serviços de suporte e regulação: serviços que mantêm os processos ecossistêmicos e as condições dos recursos ambientais naturais, de modo a garantir a integridade dos seus atributos para as presentes e futuras gerações; c) serviços culturais: serviços associados aos valores e manifestações da cultura humana, derivados da preservação ou conservação dos recursos naturais;

Nas palavras de MILARÉ, MACHADO (2012), os serviços de aprovisionamento ou de provisão correspondem àqueles obtidos diretamente da natureza pelo manejo sustentável dos ecossistemas, que fornecem bens passíveis de utilização direta pelos seres humanos, tais como: alimentos, água doce, matérias-primas, plantas medicinais, fibras, madeira, raízes, carvão, lenha, óleos.

Já os serviços de suporte e regulação, na visão dos doutrinadores citados (MILARÉ e MACHADO, 2012) são aqueles que mantêm as condições naturais dos processos físicos, a exemplo dos que auxiliam no controle do clima e na formação do solo, como: polinização, 
ciclo das águas, controle de doenças e pragas, fotossíntese, controle de enchentes e de erosão, ciclagem de nutrientes, dispersão de sementes.

Por fim, ainda nos termos do referido PL, para efetivação de uma política de pagamento por serviços ambientais poderão ser empregados os seguintes instrumentos: planos e programas de pagamento por serviços ambientais; captação, gestão e transferência de recursos, monetários ou não, públicos ou privados, dirigidos ao pagamento dos serviços ambientais; assistência técnica e capacitação voltadas à promoção dos serviços ambientais; inventário de áreas potenciais para a promoção de serviços ambientais e Cadastro Nacional de Pagamento por Serviços Ambientais.

Além do PL ora analisado, verifica-se a tramitação do Projeto de Lei da Câmara $n^{\circ}$ 312/2015, apresentado em 10 de fevereiro de 2015, também com a proposta de instituir uma Política Nacional de Pagamento por Serviços Ambientais. No PL 312/2015, os serviços ambientais são conceituados como iniciativas individuais ou coletivas que podem favorecer a manutenção, a recuperação ou a melhoria dos serviços ecossistêmicos.

Neste PL mais recente, o pagamento por serviços ambientais é conceituado como uma transação contratual mediante a qual um pagador, beneficiário ou usuário de serviços ambientais, transfere a um provedor desses serviços, recursos financeiros ou outra forma de remuneração, nas condições acertadas, respeitadas as disposições legais e regulamentares pertinentes.

De forma um pouco distinta do PL 5487/2009, o conceito de serviços ambientais contido no PL 312/2015 fornece uma ideia mais precisa de que para que se concretizem tais serviços deve haver uma iniciativa de alguém, individualmente, ou de forma coletiva, em prol do meio ambiente, sendo que a palavra iniciativa deve remeter ao aspecto da voluntariedade.

E quanto ao conceito da política de pagamento por esses serviços, os dois PLs deixam claro que deve haver duas partes envolvidas, o pagador e o provedor de serviços ambientais, e ainda de uma forma um pouco distinta, os dois PLs dispõem que poderá haver remunerações financeiras envolvidas, ou não, sendo que o PL 5487/2009 conceitua o referido pagamento como retribuição, monetária ou não, a determinadas atividades humanas, e o PL 312/2015 conceitua o pagamento como transação contratual, em que há transferência de recursos financeiros ou outras formas de remuneração.

A diferença está no fato do segundo PL indicar a necessidade de um ajuste contratual de modo a viabilizar esses pagamentos, o que vai ao encontro do conceito apresentado por ALTMANN (2010) e descrito anteriormente. O PL 312/2015 ainda propõe 
que os serviços ambientais não remunerados monetariamente sejam remunerados por meio de melhorias sociais à comunidade.

Pela observação dos conceitos dispostos nos dois projetos de lei em âmbito federal, que consideramos relevantes para as tratativas do tema em análise, é possível concluir que os serviços ambientais devem decorrer de iniciativas voluntárias, que podem vir a ser remuneradas monetariamente ou não.

\section{CONSIDERAÇÕES FINAIS}

O objetivo deste artigo foi delinear um panorama geral do Pagamento por Serviços Ambientais no Brasil. Para tanto, foram analisados conceitos e classificações de PSA, bem como os principais objetivos do instituto, fazendo referência à legislação existente e às iniciativas desenvolvidas no Brasil. Por fim, foram mencionados os projetos de lei considerados mais relevantes sobre o assunto.

A partir da investigação realizada, verificou-se que os sistemas de PSA podem ser reconhecidos como uma política pública ambiental válida, em consonância com as previsões constitucionais, destinada à conservação e uso sustentável dos ecossistemas, fundamentada em princípios do Direito Ambiental e na Constituição da República de 1988, ainda que a lógica do Pagamento por Serviços Ambientais não seja pautada no estabelecimento de punição por atos prejudiciais ao meio ambiente, ou seja, em mecanismos de comando e controle.

É cediço que as normas de comando e controle em vigor no Brasil, isoladamente, não são suficientes para coibir a prática de condutas degradantes ao meio ambiente, uma vez que infrações e crimes ambientais continuam ocorrendo regularmente. Sobre o assunto, ALTMANN (2010) preceitua que muito embora o Direito Ambiental esteja em construção permanente, esses instrumentos de comando e controle não alcançaram no país a efetividade necessária para fazer frente aos complexos problemas ambientais, gerando um crescente conflito entre crescimento econômico e preservação do meio ambiente.

Nesse sentido, o Relatório-Síntese da Avaliação Ecossistêmica do Milênio de 2005, apresentado pelo Comitê do Meio Ambiente encarregado da Análise dos Objetivos do Milênio, já apontava que uma das ações necessárias para se assegurar a conservação e o uso sustentável dos ecossistemas é a maior utilização de instrumentos econômicos, como, por exemplo, o Sistema de Pagamento por Serviços Ambientais. Assim, ao se remunerar ou 
incentivar práticas que buscam a conservação e o uso racional dos recursos naturais, o Estado estará trazendo particulares para o mundo da legalidade, inclusive aqueles com histórico infracional, que perceberão que cumprir as normas ambientais pode trazer benefícios, sobretudo econômicos.

Por outro lado, ALTMANN (2010) pontua que para a implantação de projetos de PSA no Brasil é desejável um marco legal. Por meio da instituição da Política Nacional de Serviços Ambientais, o Poder Público e a sociedade passarão a contar com novas estratégias de preservação e recuperação dos ecossistemas que prestam tais serviços. $O$ autor complementa que considerar o meio ambiente como prestador de serviços ambientais, que resultem em condições adequadas à sadia qualidade de vida, significa reconhecê-lo como parte do processo econômico, social e cultural do país - e não mais como mero fornecedor de matéria-prima e receptor de resíduos.

Contudo, conforme analisado neste artigo, apesar da ausência de uma regulamentação legal específica que institua uma política sobre o PSA no Brasil, há inúmeros projetos em curso no país que visam incentivar e remunerar, direta ou indiretamente, práticas conservacionistas desenvolvidas por particulares em âmbito federal, estadual e municipal. Todavia, defendemos o posicionamento de que somente a partir da instituição de um marco legal sobre o tema, padrões e procedimentos serão definidos com o intuito de uniformizar as práticas já existentes, atingindo todo o território nacional, funcionando como um manual para uma maior difusão do uso desse instrumento e suprimindo um vácuo legis lativo.

Na visão de ALTMANN (2010) o Sistema de Pagamentos por Serviços Ambientais possui reflexos sociais significativos ao contribuir para o aumento da renda de pequenos proprietários e agricultores familiares, contribuindo também para a produção de alimentos no país e permanência de parte da população em áreas rurais. LAVRATTI e TEJEIRO (2013) completam que o PSA contribui para a melhora das condições de vida de populações que habitam áreas ecossistemicamente ricas, tais como povos indígenas, populações tradicionais, assentados de reforma agrária e pequenos proprietários.

Por todo o exposto, concluímos que o PSA pode e deve ser utilizado no Brasil em todo seu potencial, e que já temos iniciativas esparsas e bastante promissoras nesse sentido, contudo a legislação pátria deve passar a contar com uma norma federal que sistematize as normas regulamentadoras desse instituto, uma espécie de Política dos Serviços Ambientais, com a maior brevidade possível, o que inclusive pode ser alcançado com a aprovação de projetos de lei sobre o tema, já existentes e em trâmite no Congresso Nacional. 


\section{REFERÊNCIAS BIBLIOGRÁFICAS:}

ALTMANN, Alexandre. Pagamento por Serviços Ambientais: aspectos jurídicos para a sua aplicação no Brasil. 2010. Disponível em <http://www.planetaverde.org/bibliotecavirtual/artigos-juridicos> Acesso em 10 de maio de 2015.

ALTAMANN, Alexandre. Pagamento por Serviços Ambientais como mecanismo econômico para a mitigação e adaptação aos efeitos das Mudanças Climáticas no Brasil. 2010. Disponível em 〈http://www.planetaverde.org/biblioteca-virtual/artigos-juridicos> Acesso em 11 de agosto de 2015 .

ANTUNES, Paulo de Bessa. Comentários ao Novo Código florestal: Lei no 12.651/12 atualizado de acordo com a Lei no 12.727/12. São Paulo: Editora Atlas, 2013.

AVAliAÇÃO ECOSSISTÊMICA DO MILÊNIO. Relatório-Síntese. Disponível em <http://www. millenniumassessment.org.> Acesso em 29 de março de 2015.

CARVAlHO, Lucas Azevedo de. O Novo Código Florestal Comentado: Artigo por Artigo Lei 12.651/2012, com as alterações trazidas pela Lei 12.727/2012 e Referências ao Decreto $n^{\circ}$ 7.830/2012. Curitiba: Juruá Editora, 2013.

DIREITO E MUDANÇAS CLIMÁTICAS: Pagamento por Serviços Ambientais, fundamentos e principais aspectos jurídicos / Paula Lavratti, Guillermo Tejeiro, organizadores. São Paulo: Instituto O Direito por um Planeta Verde, 2013. Disponível em $<$ http://www.institutocarbonobrasil.org.br/arquivos_web/documentos/DIREITO\%20e\%20\%2 0\%20\%20\%20\%20MUDANcAS\%20CLIMATICAS\%206.pdf> Acesso em 15 de março de 2015.

DIREITO E MUDANÇAS CLIMÁTICAS: Pagamento por Serviços Ambientais: experiências locais e latino-americanas / Paula Lavratti, Guillermo Tejeiro, organizadores. São Paulo: Instituto O Direito por um Planeta Verde, 2014. Disponível em 〈http://www.planetaverde.org/biblioteca-virtual/e-books〉 Acesso em 15 de março de 2015.

GODECKE, Marcos Vinicius; HUPFFER, Haide Maria; CHAVES, Iara Regina. O futuro dos Pagamentos por Serviços Ambientais no Brasil a partir do novo Código Florestal. Revista Desenvolvimento e Meio Ambiente, v. 31, 31-42, ago. 2014. Disponível em <http://www.ser.ufpr.br/> Acesso em 18 de abril de 2015. 
MILARÉ, Édis. Direito do Ambiente. $8^{\text {a }}$ ed. rev. atual. e ampl., - São Paulo: Editora Revista dos Tribunais, 2013.

MILARÉ, Édis; MACHADO, Paulo Affonso Leme (Coord.). Novo Código Florestal: Comentários à Lei 12.651, de 25 de maio de 2012 e à Medida Provisória 571, de 25 de maio de 2012. 1 ed. São Paulo: Editora Revista dos Tribunais, 2012.

NUSDEO, Ana Maria. Pagamento por serviços ambientais: Sustentabilidade e Disciplina jurídica. $1^{\text {a }}$. ed. São Paulo: Atlas, 2012, p. 137-139.

OLIVEIRA, Daniela Paiva. Aspectos jurídicos acerca da viabilidade do pagamento por serviços ambientais. Disponível em $\quad$ http://www.ambitojuridico.com.br/site/index.php?n_link=revista_artigos_leitura\&artigo_id=10437>. Acesso em 17 de maio de 2015.

OLIVEIRA JÚNIOR, Mauro Elói de. Pagamento por Serviços Ambientais: Uma Alternativa Importante para Conservar e Recuperar as Bacias Hidrográficas e Fornecer Água de Qualidade à População. Brasîlia, DF, 2010. Disponível em

$<\underline{\text { http } / / \text { produtordeagua.ana.go v.br/Portals/0/DocsDNN6/documentos/PSA_Fortium.doc }>}$

Acesso em 24 de março de 2015.

ROSSI, Fernando F. et al. (Coord.). Aspectos controvertidos do direito ambiental: tutela material e tutela processual. Belo Horizonte: Editora Fórum, 2013.

SANTOS, Priscilla; BRITO, Brenda; MASCHIETTO, Fernanda; OSÓRIO, Guarany; MONZONI, Mário (Org.). Marco Regulatório sobre Pagamento por Serviços Ambientais no Brasil. Belém, PA: IMAZON; Fundação Getúlio Vargas. CVces, 2012. Disponível $<$ http://imazon.org.br/marco-regulatorio-sobre-pagamento-por-servicos-ambientais-nobrasil/> Acesso em 15 de março de 2015.

WALDMAN, Ricardo Libel; ELIAS, Luiz Augusto da Veiga. Os princípios do Direito Ambiental e o Pagamento por Serviços Ambientais/Ecossistêmicos (PSA/PSE). Revista de Direito Ambiental RDA, Ano 18, vol. 69, jan. - mar. 2013. 